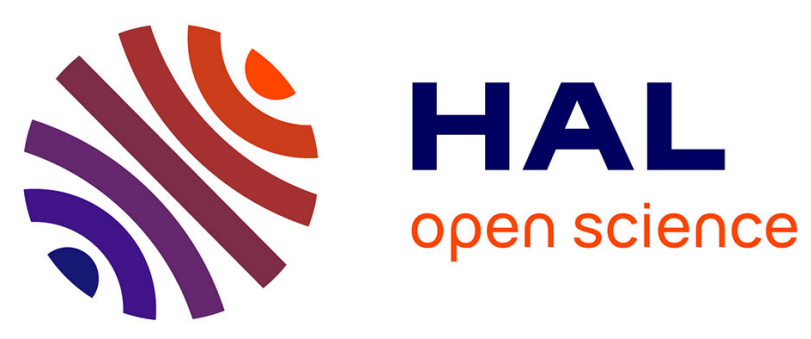

\title{
Legal Human Rights Theory
}

\author{
Samantha Besson
}

\section{To cite this version:}

Samantha Besson. Legal Human Rights Theory. Kasper Lippert-Rasmussen; Kimberley Brownlee; David Coady. A Companion to Applied Philosophy, 63, Wiley Blackwell, pp.328-341, 2016, Blackwell Companions to Philosophy, 978-1-118-86913-0. 10.1002/9781118869109.ch23 . hal-02516346

\section{HAL Id: hal-02516346 https://hal.science/hal-02516346}

Submitted on 11 May 2020

HAL is a multi-disciplinary open access archive for the deposit and dissemination of scientific research documents, whether they are published or not. The documents may come from teaching and research institutions in France or abroad, or from public or private research centers.
L'archive ouverte pluridisciplinaire HAL, est destinée au dépôt et à la diffusion de documents scientifiques de niveau recherche, publiés ou non, émanant des établissements d'enseignement et de recherche français ou étrangers, des laboratoires publics ou privés. 


\section{3 \\ Legal Human Rights Theory}

SAMANTHA BESSON

\section{Introduction}

This chapter pertains to the meta-theory of human rights and, more specifically, to the method of human rights theory or philosophy. It argues that human rights theory should take the legal nature of human rights more seriously. The proposed human rights theory, that is, a legal theory of human rights, implies doing two things. First, human rights theorists should start from the current human rights legal practice as an object and resource of justification and critique, and not from ideal and/or abstract moral theorizing as most of them have done so far. Second, however, they should address those questions philosophically, and not only legally as human rights lawyers do.

The hope is that, in so doing, the proposed legal theory of human rights can bridge the gap between current theorizing of human rights by philosophers (even the most applied ones) and by lawyers: philosophers either see human rights law as a mere translation or enforcement of moral human rights (e.g., Griffin 2008; Tasioulas 2010), or take it as a static and conservative reality that one can then reconstruct morally (e.g., Beitz 2009; Rawls 1999), while lawyers' dogmatic discussions of human rights law do not easily embark into normative theorizing or, paradoxically, only by reference to certain kinds of ideal moral theorizing (e.g.. Clapham 2007; also, in a more nuanced way, Luban 2015; cf. Chapter 20. Non-ideal Theory). The chapter may also be read as a contribution to the discussion of what applied philosophy amounts to, especially when it pertains to legal norms such as human rights.

Thinking about the nature of human rights theory is important for at least two reasons. First of all, it enables a human rights theory to situate itself within a broader set of theories, and in particular legal theory, democratic theory, or theories of justice. This in turn can generate beneficial connections between them. Given the centrality of human rights to human social and political life, the quality of their theories is often 
undermined by the artificial severance of those connections. Second, thinking about the nature of a theory requires a preliminary clarification of what it is a theory of and, therefore, of the nature of human rights (e.g., Raz 2009 on the nature of law and of legal theory). Such preliminary considerations can prove very beneficial in fully identifying or at least delineating the object of one's theoretical endeavor. The answers to many of the important questions human rights theorists identify as being central to human rights theory - and, in particular, the justification of human rights (e.g., Besson 2013a, 2014) - are indirectly, and often involuntarily, conditioned by theorists' original characterization of the nature of their theory and its object. Actually, because they do not always make the nature of human rights and hence the object of their respective human rights theory explicit, many human rights theorists actually argue at cross-purposes (see Buchanan 2013's critique of Tasioulas and Beitz).

Still, most contemporary human rights theorists (e.g., Beitz 2009; Buchanan 2004; Griffin 2008, 2010; Nickel 2007; Raz 2010a, 2010b; Tasioulas 2009; Wellman 2010) do not spend much time theorizing about the nature of their theory and, more specifically, about the legal dimensions of that theory. This is surprising, as the idea of human rights itself is usually regarded as being a moral, a political, and a legal one (e.g., Besson 2011; $\operatorname{Raz} 2010 \mathrm{a}: 336-337)$. While one may understand why a moral philosopher or a political scientist may not want to reduce human rights qua moral standards or political practice to legal rules and principles, understanding the legal dimension of those standards or practice and/or their interaction with the law of human rights would seem to be an important part of the elucidation of their broader moral and political nature.

True, of all areas of international law, international human rights law is the most likely to trigger questions pertaining to the role of morality, not only in its practice but also in its theorizing. This is because the content of international legal human rights and that of their moral correspondents are often taken to overlap. It is also because their justification is sometimes taken to transcend their legal enactment - at least on the face of international human rights instruments' preambles or judicial reasoning on those grounds (Besson 2013a; Luban 2015; Nickel and Reidy 2010). Reacting too quickly to this moral dimension of legal human rights, however, recent human rights theories seem to be focusing almost exclusively on the moral nature of human rights and see their relationship to the law as going one way only: the transposition and implementation of moral rights into law (e.g., Griffin 2008, 2010; Nickel 2007; Tasioulas 2009, 2010; Wellman 2010. For a similar critique of what he calls the "Mirroring View," see Buchanan 2013, 2015). Those few accounts that have distanced themselves from this form of abstract moral theorizing about human rights consider them as purely political practices, of which the law is just one instantiation or where the law is treated as a static and morally inert reality (e.g., Beitz 2009; Rawls 1999; Raz 2010a, 2010b). As a result, most recent human rights theories have not only neglected the specifically legal dimension of human rights and how the law contributes to the recognition and specification of human rights qua moral rights, but have also artificially severed the links between human rights theory qua moral theory, on the one hand, and legal theory, on the other.

My argument will unfold in four steps. In the first section, I will start by explaining why we should take human rights practice as our object in human rights theory and not the abstract moral reality of human rights, and in particular why we should focus on 
the legal practice of human rights. Second, I will challenge the divide between so-called ethical and political accounts of human rights one meets in current human rights theory and argue that taking the legality of human rights seriously may help to bridge the gap between them. In the third section, I will explain what a legal theory of human rights should look like and what its methodological characteristics should be. Finally, I will show that legal human rights theory may be considered a form of applied philosophy.

\section{From Human Rights Practice to Human Rights Theory: Law as the Missing Link}

\section{Human Rights Theory qua Theory of a Practice}

Human rights theory aims, in a broad and uncontested sense, at providing the best philosophical account of human rights.

To do so, the stated aims of most human rights theories to date are largely the same: understanding the nature and function of human rights; determining the object, normative content, right-holders and duty-bearers of human rights; and providing a justification of human rights (e.g., Beitz 2009: 11; Nickel 2007: 7; Raz 2010a, 321$337,322)$. Additionally, some human rights theories also aim at providing critical normative guidance to human rights practice (e.g., Buchanan 2013; Lafont 2013). It follows from the aims human rights theories share that, in order to attain them, they should be focusing on the contemporary human rights practice qua object of philosophical enquiry.

Of course, some human rights theorists prefer to focus on the moral reality of human rights independently from their practice. They explain human rights by reference to moral interests and values and to moral duties only. The difficulty, however, is that most of those theorists still state that their philosophical endeavor aims at accounting for, or even improving, the contemporary human rights discourse (e.g., even Griffin 2008: 1-6; Tasioulas 2010, 2016). Few of them, indeed, would relish speculating over an abstract moral reality without any relationship to our daily life. This is even more the case when their object is one that plays the kind of eminent role human rights have in our moral and political lives.

So, what some of those human rights theorists have done in reaction to this methodological critique is to qualify their object. They insist that their human rights theory pertains to elucidating not so much the human rights practice itself, but the concept of human rights as it is embedded within our contemporary human rights practice (e.g., Tasioulas 2012, 2016).

There are many difficulties with this conceptual approach to human rights. One of them is that there presumably are many concepts of human rights at play in the human rights practice at any given time and across history. As such, conceptual analysis is unlikely to be easy and to reveal much about the practice of human rights. As a matter of fact, the further you go back in history, the harder it becomes to isolate a single concept and one that is still embedded in our practice today (e.g., Griffin 2008: 1-2). This may explain why most human rights theorists focusing on the concept of human 
rights identify what they take to be our current human rights practice's concept of human rights (e.g., Tasioulas 2012, 2016).

The second difficulty raised by this focus on an abstract concept of human rights is that it provides yet another way to retreat back to the moral dimension of human rights to the exclusion of other dimensions in the practice (e.g., Tasioulas 2012). In so doing, these human rights theorists fall back into the kind of abstract moral theorizing of human rights they seemed to break away from in the first place. The problem then is that any correspondence between the abstract concept of human rights they are elucidating and the practice of human rights they took it from is bound to be fortuitous. In turn, the evaluative force of such a human rights theory becomes as thin as that of any external moral judgment of the practice. To quote Raz (2013: 4), "even true human rights theories should not be the standards by which to judge human rights practice." Of course, if there is such an abstract moral concept of human rights in their practice, it will have to feature in one's theory of the human rights practice, but this concept is not in itself a normative theory of that practice (Raz 2013: 7). Conceptual analysis and the elucidation of the meaning of that concept cannot illuminate significant ethical or political issues about the practice of human rights (Raz 2010a: 321-337).

Instead, it is by grasping the aims of the contemporary human rights practice and by understanding its significance and distinctive functions that one gets to the interpretive material that will enable one to establish the nature, structure, and justification of human rights. As Lafont (2013) explains, "it is by understanding the point of the practice of human rights that we understand what human rights actually are." The crucial question, then, becomes identifying the human rights practice one ought to account for philosophically and determining how one may get to the point of that practice.

\section{Human Rights Theory qua Theory of a Legal Practice}

Few of the human rights theorists focusing on the practice of human rights have provided a clear account of what they mean by the human rights practice (see, however, Beitz 2009; Buchanan 2015). It is usually described as a complex ensemble of political and legal practices. Some prefer referring to a discourse, but fail to explain what that discourse amounts to. Most of the time, it is considered as a morally inert set of social facts.

Interestingly, legal theorists are used to understanding their object - that is, the law - as a practice, and more specifically as a normative practice. Indeed, the law amounts to a practice where abstract moral ideas meet social facts and where both are in mutual tension. This makes human rights law (as legal practice) an interesting case for the human rights practice in human rights theory, and, in turn, legal theory an attractive resource for human rights theory to account for that object.

Of course, some may say, and rightly so, that the human rights practice cannot be reduced to human rights law. They refer, for instance, to the anti-slavery or the feminist movements whose human rights claims were not articulated in legal terms. One may quibble with those assertions, especially on historical grounds. At some point, indeed, the law was always in the background of the claims made, at least as models for how to shape those claims. Moreover, even the idea of natural rights was articulated most effectively in practice at times at which it could also take a legal form, for instance 
through constitutional claims in the context of the American and French revolutions. In any case, it suffices to be able to show that human rights law is central to our contemporary human rights practice, even if it does not exhaust that practice nowadays, on the one hand, and even if it was not always the case throughout the history of human rights, on the other.

The centrality of law in current human rights practice is easy to establish. Most human rights claims are articulated by reference to some legal basis in the Universal Declaration of Human Rights, an international human rights treaty, or in the decisions of an international human rights institution or court. Of course, conversely, international human rights law also refers to the moral justification of legal human rights (see Besson 2011, 2013a; Buchanan 2015; Gilabert 2011: 449; Luban 2015). Thus, from the use of the idea in our daily discourse, we know that human rights are both a moral idea and a legal one. The same may be said of other related ideas such as dignity (Waldron 2012, 2013), for instance, or responsibility.

There are two ways of approaching a centrally legal notion like human rights as a normative philosopher: either as a pre-institutional moral idea constraining the law and the practice (even imperfectly so) or through law and the normative practice of moral ideas in legally institutionalized circumstances (Waldron 2012). While the first approach may seem right to those philosophers who regard the law and general political practice as mere instantiations of morality, I would like to argue that the second is more appropriate: in most instances of ideas present in both law and morality, the law is not only constrained by moral ideas, but also influences their normative scope and justification. The relationship between moral norms and their legal correspondents goes both ways, as a result: it is not merely a matter of translation, transposition, or specification in the law (what one may coin the "one-way" view), but the law can also be a generator of moral norms and of moral normativity in social circumstances (the "two-way" view). In those cases, it is much more interesting and encompassing methodologically to start from legal norms and move back and forth to moral ones.

This is particularly illuminating in the case of human rights. Human rights do not usually enter our ordinary conversations about interpersonal morality. And when they do, it is in relation to the law and to politics, at least by analogy. For instance, human rights are usually explained in relation to social and political status, and status is a legal notion. They are also held to give rise to institutional duties, and this in turn implies a legal order. Thus, when human rights do enter our discussions in moral philosophy, this corresponds to little more than an appropriation of the idea by philosophers, for instance in order to make sense of other moral ideas such as justice, equality, or democracy. If this is correct, the best philosophical approach is to start with human rights in the law, both domestic and international, and to account for them the way legal philosophers account for the law. This is what one should refer to as the legal theory of human rights.

Of course, something may be a legal principle or right without corresponding to a moral principle or right. It may even be morally justified as a legal principle or right without having a pre-legal moral correspondent (e.g., Buchanan 2015; Buchanan and Sreenivasan 2016). The danger then is that, by focusing only on the legal idea of human rights, one may miss the moral target. The reverse may also be feared, however. Not all universal moral rights are protected by legal means, even less so by legal rights. It is important to stress at the outset, therefore, that so-called legal human rights may exist 
independently from corresponding moral rights and may even be justified morally without reference to their corresponding moral rights, on the one hand. Conversely, one should also emphasize that not all universal moral rights may give rise to legal protection and legal rights, on the other.

Still, in most cases, there is a mutual relationship between moral and legal human rights. Those cases are the most interesting ones to consider from a normativetheoretical perspective. As I have argued elsewhere (Besson 2011, 2012a, 2013a, $2015 a, 2015$ c), indeed, human rights can be considered as rights in a moral sense only when legal human rights correspond to universal moral rights whether through legal recognition or specification. And, conversely, universal moral rights can be considered as human rights, that is, as equal and feasible rights, only once they are institutionalized and hence guaranteed as legal rights. In a nutshell, the former statement may be justified by reference to what rights are tout court and hence to what legal rights should amount to in order to be considered (moral) "rights." The latter, in short, finds its justification in the institutional nature of human rights and their duty-bearers, which itself can be justified by reference, first, to the equality of human rights and in particular to the fact that they are rights of all against all; and, second, to the practical need for the institutional and legal mediation of the identification and allocation of human rights duties for those to be feasible and hence to be owed to a right-holder and to be able to give rise to a moral right.

So, the truth lies in the middle. Following Waldron $(2009,2012)$, one may consider that the law contains, envelops, and constitutes normative justifications: it does not just borrow them from morality. Things that appear to be normatively "deeper" in the law are not necessarily purely moral: the law encompasses morality, and molds and specifies it. The law is not morally inert and the normativity of law is a special kind of moral normativity. Following Raz (2016), one may say that the law has a double moral life to the extent that it may be both the object of a moral normative assessment and itself a source of moral norms. The law's pivotal role in the framework of moral normativity illuminates how human rights law may be both an object of moral assessment and, in turn, a source of new moral norms. It may be both an object of moral critique and a resource for moral reform, and all this internally to the legal practice.

It follows that when we think philosophically about human rights law, we evaluate human rights law morally albeit by using its own law-immanent human rights resources and standards (Waldron 2012). As a result, accounting for our contemporary human rights practice requires neither purely abstract moral theorizing nor mere legal description, but what legal philosophers are used to doing: theorizing the law in order to identify its immanent morality and hence the immanent critique within the law as a normative practice.

\section{The Law in "Political" and "Ethical" Human Rights Theories}

Two main groups of human rights theories have arisen in recent years: so-called "ethical" (e.g., Beitz 2009; Raz 2010a) and "political" (e.g., Griffin 2008; Tasioulas 2012; see Chapter 20, Non-ideal Theory) theories of human rights. I am referring to those two categories here only to capture a difference of views pertaining to the nature 
of human rights, and not the latter's function and justification (on these other dimensions of the division, see, e.g., Forst 2010; Nickel 2016; Tasioulas 2009, 2010).

Importantly for our purpose in this chapter, neither of these two groups of human rights theories gives human rights law much consideration when assessing the nature of human rights. Nor, however, do they bring the resources of legal theory into their meta-theoretical project. Remedying their neglect of the legal dimension of human rights may help, however, bridging the divide between them and explaining how they can both help capturing something important about the moral and political dimensions of human rights provided they are brought together through human rights legal theory. Other authors have argued for a combination of both approaches (e.g., Gilabert 2011: Miller 2015; Valentini 2012), but not based on a legal argument about the nature of human rights (see also Besson 2011, 2013b).

At first, "political" and "ethical" theories of human rights' neglect of the legal dimension of human rights may look surprising. Indeed, it is precisely their diverging concern for the practice of human rights, including, presumably, their legal practice, that is said to lie at the core of their opposition. One explanation may actually lie in a fundamental distinction made in all or most of these human rights theories: the opposition between the concrete practice of human rights and the abstract standards of human rights. "Political" and "ethical" human rights theorists alike claim they are (also) writing about human rights as a political practice, and not (only) about human rights as abstract moral standards. Doing so, most of them want to distance themselves from a top-down approach and choose instead a practice-oriented or bottom-up approach (e.g., Beitz 2009; Raz 2010a: 322-327 for "political" approaches; and Griffin 2008: 29; Tasioulas 2009: 939 for "ethical" approaches), or what they sometimes refer to as a "middle-game" or "middle-level" approach (e.g., Nickel 2007: 3; see also Beitz 2009: 127, 212).

The problem is that neither of these two approaches actually succeeds in bridging the gap between human rights standards and human rights practice. The former fail to explain how they can construct a human rights account from legal practice and then criticize it from a normative stance (this is one of the problems with the two-step approach in Beitz 2009, 126-128). The latter are unclear about how they can focus on abstract standards distinct from human rights practice and then demonstrate enough "fidelity" to the legal practice on that basis (e.g., Griffin 2008: 29, 204, 209-211; Tasioulas 2009: 939; for a similar critique, see Raz 2013: 6).

One of the reasons for human rights theorists' difficulties in bridging this gap between standard and practice lies, I would like to argue, in their failure to understand the inherently legal nature of human rights (Griffin 2008: 191; Miller 2015; Nickel 2007: 32-33; Sen 2009: 364-366; Tasioulas 2007: 84-85) or, at least, to understand it fully (Beitz 2009: 209-212; see, however, Cohen 2008: 599-600; Raz 2010b). They actually assume they have taken the legal dimension of human rights into account by drawing the opposition between human rights practice and human rights standards and making it a central part of their theoretical poise on human rights. But what they have done in fact is reduce the law to one side of the equation by conflating it with one of the dimensions of human rights practice. No wonder, in these conditions, that human rights law is regarded by those authors as playing a secondary role, if any at all, in human rights theory. 
It is important not to confuse the relationship between abstract standards and concrete practice, on the one hand, with the relationship between human rights as ethical or moral standards and human rights as legal norms, on the other. It is true that human rights law can play a crucial role in the enforcement of human rights standards in practice by specifying human rights duties in concrete circumstances. However, it can also contribute to the identification and specification of those standards at an abstract level, either through the recognition of interests as sufficiently fundamental to give rise to human rights, or through the recognition or specification of moral rights themselves. As I explained before in relation to the egalitarian and mutual institutional mediation of human rights, what I have in mind here does not amount only to the legal recognition and specification of pre-legal moral rights, but also, and more importantly, to their identification and specification as human rights in the first place. This includes the identification of the relevant general interests and standard threats through the legal process, on the one hand, and the legal abstract assessment of the feasibility of the corresponding duties and of the fairness of the potential burden on their duty-bearers, on the other.

As a matter of fact, the difficulties that beset the opposition between human rights practice and human rights standards echo the complex relationship between facts and norms in legal practice. Legal theorists have long learned to explain the law qua normative practice. It seems, therefore, that by not paying sufficient attention to the legal nature of human rights and by conflating the law of human rights too quickly and exclusively with their politics or practice, current human rights theories miss a central component of the normative practice of human rights, thus impoverishing their substantive moral account of human rights. Worse, they deprive themselves of essential theoretical insights about the nature of normative practices and, hence, of theoretical resources in their efforts to bridge the gap between human rights as critical moral standards and the political practice of human rights.

\section{Human Rights Theory qua Legal Theory}

The method of legal theorizing of human rights I propose draws from those of analytical legal philosophy and, more particularly, from those of normative positivism. More specifically, it finds some of its inspiration in both the legal philosophy of Raz (e.g., 2010b, 2013) on the normativity of law and legal rights and that of Waldron (e.g., 2012) on legal interpretation.

The aim is to link these jurisprudential considerations to the methodological proposals made by non-ideal and institutional political theorists of human rights (e.g., Buchanan 2004). This should help focusing the latter's institutional human rights theories even more on the law and working out the way in which human rights law provides its own human rights critique. Importantly, indeed, the most institutional and law-sensitive of human rights theories to date, and in particular Buchanan's (2013), do not go far enough in this respect. Buchanan purports to provide a moral evaluation and justification of the international human rights legal system, and not to explain how that evaluation and justification work inside the legal system itself. His argument remains largely moral and external to the law, as a result. 
The main characteristics of the proposed method are the following. First of all, human rights theory needs to start with the hard questions raised by the legal practice of human rights, and not with those identified by moral philosophers. This should bring to the fore some questions that have not been addressed by human rights theorists so far. One example is the controversial notion of "jurisdiction," that is, the condition of effective government-like control that works as a condition set in international human rights law for the applicability of human rights (e.g., Besson 2012b, 2015c). Second, human rights theory should not take human rights law only as a starting point, but also as both an object of justification and critique and a resource for that justification and critique. Legal human rights theory does not take human rights practice as a given, but criticizes it albeit without disparaging it as soon it does not fit an a priori moral concept. An example of the relevance of those resources is the discussion of the justification(s) of human rights. Once human rights' (especially judicial) reasoning is understood as justificatory, for instance in the specification and allocation of human rights' duties and their restriction, it becomes clear that the quest for their justification(s) is best lócated within that reasoning (Besson 2013a).

This enables legal human rights theory to avoid the Charybdis of conservatism that besets "political" theories and the Scylla of revisionism that threatens "ethical" ones. Of course, the balance between justifying and criticizing is not easy to keep and the interpretive constraints are difficult to identify with precision. Moreover, the legal practice of human rights may not always be morally correct. All the same, it is sometimes legitimate even so due to the epistemological or social constraints applicable in circumstances of reasonable moral disagreement (e.g., Buchanan 2008). One example is proportionality and the balancing of human rights' duties when they conflict; while one may object to them from an abstract moral perspective, they may be justifiable from within the judicial practice of human rights (Letsas 2015).

Besides taking the law seriously and drawing on the resources of analytical jurisprudence, the proposed legal theory of human rights has many advantages for our understanding of human rights when compared with other human rights theories. First of all, it is a better guide to the practice and to its potential reforms: it helps understanding how the practice includes the resources to reform itself and can help resorting to them. Second, given the close relationship between legal theory and practice, legal human rights theorizing places the theorist at the core of the human rights practice and helps understanding his or her central role in the organization of the practice (see also Beitz 2009: 8-9, 212) without, however, turning him or her into a philosopher-king. Third, legal human rights theorizing helps to connect philosophical approaches to human rights to other disciplinary approaches such as human rights history in particular (Besson and Zysset 2012). Thus, a legal approach to human rights makes a virtue out of the institutionalization and hence relative contingency of human rights.

The proposed legal theory of human rights ought to be distinguished from other existing legal theories of human rights, and in particular from Wellman's (2010) and Dworkin's (2011).

Wellman's theory of human rights, first of all, starts from an opposite observation: according to him, the moral underpinnings of legal human rights are not sufficiently explicit in recent human rights theorizing and need to be accounted for. Unlike the hereby proposed theory, Wellman's sees current human rights theorizing as under-moralized and 
aims at remedying this. His theory is not interested therefore in the ways in which the law includes moral doctrines and principles and is actually essential to human rights practice, and not just an add-on to an independentset of universal moral rights. Secondly, Dworkin's account of human rights comes close in its interpretive dimension to the proposed legal theory of human rights. Where we differ, however, is in relation to international human rights law and its differences from domestic human rights law. Those differences prevent a mere transposition of one's theory of constitutional rights to human rights (e.g., Letsas 2007). But, most importantly from a methodological perspective, our divergence lies in the non-positivist flavor of Dworkin's account and his conflation of law and morality.

\section{Legal Human Rights Theory as Applied Philosophy}

\section{Legal Theory as Applied Philosophy}

The final question to raise in a book like this one is whether the proposed legal human rights theory is a form of applied philosophy and, if so, in what sense. We should first zoom out to legal theory in general and discuss how it may qualify as applied philosophy, before zooming back onto legal human rights theory.

There are many legal theories and stark differences between them, whether in methodological terms or in terms of aims and audience. Roughly speaking, and not necessarily in a mutually exclusive fashion, some are descriptive while others are normative; some are practice-oriented while others pertain more to the structure and principles of law; and so on.

Of course, what all legal theories have in common is their object: the law, and hence a practice. Interestingly, however, this does not necessarily make them more applied than other philosophies. True, all of them fit one of the forms of applied philosophy discussed in Kasper Lippert-Rasmussen's chapter (Chapter 1, The Nature of Applied Philosophy). And this is because, given the centrality of their object - the law - to our lives, legal theories are clearly relevant to important questions of everyday life.

As to the other characteristics of applied philosophy, however, they may not always be verified depending on the legal theory at hand. First of all, descriptive legal theories aim at describing the law and are not practical, therefore. They do not answer questions about what we ought to do, unless one considers describing and accounting for a practice that is normative, and hence for the law's authority and normativity, as practical enough. Second, and for the same reasons, some legal theories are not motivated by any ambition of having a causal effect on the world. They merely aim at accounting and explaining the law. Others, by contrast, openly endeavor to provide the best interpretation of the law to affect how it is practiced and consider legal theory as part of the normative practice of law. Third, while some legal theories may resort to empirical evidence, especially economic and sociological theories of law, not of all them do. of course, for reasons of their object being a normative social practice, legal theorists are generally more interdisciplinary than many other philosophers. As I have argued elsewhere, one may even doubt whether their "interdisciplinarity" is really about bringing other disciplines into legal theorizing, and not simply a matter of the latter being interdisciplinary in itself as a discipline (Besson 2015b). 
Finally, one may also mention the characteristic that legal theories' intended audience includes some or only non-philosophers. However, this point only works if one considers lawyers as non-philosophers. As a matter of fact, some legal theories are addressed to lawyers, while others are only to be discussed with other legal theorists or even other philosophers at large. As a matter of fact, the embeddedness of legal theory in the practice of non-theorists is one of the main ambitions of some legal theories (e.g., Dworkin 1986: 91). Of course, this may question their philosophical nature. In case those legal theories are to be considered as applied philosophy, however, it may be best to qualify them as self-reflexive applied philosophy in order to mark their mutually constitutive relation to the practice they are a part of.

\section{Legal Human Rights Theory as Applied Philosophy}

Qua normative legal theory, the legal human rights theory I have proposed in this chapter fits some of the forms of applied philosophy discussed in Lippert-Rasmussen's chapter.

This is clearly the case for the following features. First of all, it is relevant to important questions of everyday life given how human rights protect our basic interests. Second, it is part of the human rights practice and hence also addressed at nonphilosophers. Third, it is normative, and hence practical to the extent that it answers questions about what we ought to do. Fourth, it aims at improving our practice of human rights by clarifying and reforming it. Finally, it is informed by empirical evidence to the extent that it starts with the questions raised in courts and other human rights institutions.

As a matter of fact, the legal features of the proposed human rights theory definitely make it more applied than other legal theories. They also make it more applied than other human rights theories for it is more attuned to the legal nature of human rights. Importantly, legal human rights theory embraces more dimensions of applied philosophy than applied ethics. It is a normative theory that pertains not only to what we ought to do on grounds of human rights, but also to how we should identify and justify them. This branches into considerations of applied epistemology - for example, with respect to human rights reasoning - but also of applied metaphysics as with respect to the potential justifications of human rights (Besson 2013a). As a result, the proposed human rights theory cannot be reduced to yet another field of more or less specific applied ethics.

\section{Conclusion}

This chapter's concern was primarily meta-theoretical and its question pertained to the nature of human rights theory. It has argued in favor of taking the legal dimension of human rights more seriously and developing a legal theory of human rights.

Legal human rights theory has two advantages: one substantive and the other methodological. First of all, understanding the legal dimension of human rights makes for a deeper understanding of the nature of human rights themselves, and hence of all the other questions in human rights theory such as the justification of human rights in 
particular. A second benefit of taking the legal dimension of human rights seriously is that human rights theorizing can be done as legal theorizing and make use of the resources of jurisprudence, and in particular of analytical legal philosophy.

This substantive and methodological proposal comes at a time when current human rights theorizing has locked itself in a dead end through a self-imposed division between "political" and "ethical" accounts. As commentators have started arguing, however, that division has largely become sterile as the best account of human rights ought to combine the substantive and methodological strengths of both. Understanding human rights as "legal" and human rights theory as "legal" does not only help combining most effectively the benefits of both types of accounts, but it also opens new lines of questioning and inquiring about our contemporary human rights practice that go well beyond what "political" and "ethical" theories of human rights can offer.

\section{References}

Beitz, C.R. 2009. The Idea of Human Rights. Oxford: Oxford University Press.

Besson, S. 2011. "Human Rights: Ethical, Political ... or Legal? First Steps in a Legal Theory of Human Rights." In The Role of Ethics in International Law, edited by D. Childress, 211-245. Cambridge: Cambridge University Press.

Besson, S. 2012a. "The Egalitarian Dimension of Human Rights." Archiv für Sozinl- und Rechtsphilosophie Beiheft 19-52.

Besson, S. 2012b. "The Extraterritoriality of the European Convention on Human Rights. Why Human Rights Depend on Jurisdiction and What Jurisdiction Amounts to." Leiden Journal of International Law 25(4): 857-884.

Besson, S. 2013a. "Justifications of Human Rights." In International Human Rights Law, edited by D. Moeckli, S. Shah, and S. Sivakumaran, 34-52. Oxford: Oxford University Press.

Besson, S. 2013b: "The Law in Human Rights Theory." Zeitschrift für Menschenrechte - Journal for Human Rights 7: 120-150.

Besson, S. 2014. "The Legitimate Authority of International Human Rights." In The Legitimacy of International Human Rights Regimes, edited by A. Follesdal, J. Karlsson Schaffer and G. Ulfstein, 32-83. Cambridge: Cambridge University Press.

Besson, S. 2015a. "Human Rights and Constitutional Law." In Oxford Handbook on Human Rights, edited by R. Cruft, M. Liao, and M. Renzo, 279-299. Oxford: Oxford University Press.

Besson, S. 2015b. "International Legal Theory qua Practice of International Law." In International Law as a Profession, edited by J. d'Aspremont, A. Nollkaemper, and T. Gazzini. Cambridge: Cambridge University Press.

Besson, S. 2015c. "The Bearers of Human Rights Duties and Responsibilities for Human Rights - A Quiet (R)Evolution." Social Philosophy \& Policy 32(1): 244-268.

Besson, S. and Zysset, A. 2012. "Human Rights Theory and Human Rights History: A Tale of two Odd Bedfellows." Ancilla Juris (anci.ch), Special Issue: International Law and Ethics 2012: 204-219. Buchanan, A. 2004. Justice, Legitimacy, and Self-determination: Moral Foundations for International Law. Oxford: Oxford University Press.

Buchanan, A. 2008. "Human Rights and the Legitimacy of the International Order." Legal Theory 14(1): 39-70. doi:10.1017/S1352325208080038

Buchanan, A. 2013. The Heart of Human Rights. Oxford: Oxford University Press.

Buchanan, A. 2015. "Why International Legal Human Rights?" In Philosophical Foundations of Human Rights, edited by R. Cruft, M. Liao, and M. Renzo, 244-262. Oxford: Oxford University Press. 
Buchanan, A. and Sreenivasan, G. 2016. "Taking International Legality Seriously: A Methodology for Human Rights." In Human Rights: Moral or Political?, edited by A. Etinson, forthcoming. Oxford: Oxford University Press.

Clapham, A. 2007. Human Rights: A Very Short Introduction. Oxford: Oxford University Press.

Cohen, J.L. 2008. "Rethinking Human Rights, Democracy and Sovereignty in the Age of Globalization." Political Theory 36(4): 578-606. doi:10.1177/0090591708317901

Dworkin, R. 1986. Law's Empire. Cambridge, MA: Harvard University Press.

Dworkin, R. 2011. Justice for Hedgehogs. Cambridge, MA: Harvard University Press.

Forst, R. 2010. "The Justification of Human Rights and the Basic Right to Justification. A Reflexive Approach." Ethics 120(4): 711-740. doi:10.1086/653434

Gilabert, P. 201 1. "Humanist and Political Perspectives on Human Rights." Political Theory 39(4): 439-467. doi:10.1177/0090591711408246

Griffin, J. 2008. On Human Rights. Oxford: Oxford University Press.

Griffin, J. 2010. "Human Rights and the Autonomy of International Law." In The Philosophy of International Law, edited by S. Besson, and J. Tasioulas, 339-355. Oxford: Oxford University Press.

Lafont, C. 2013. "Human Rights and the Legitimacy of Global Governance Institutions." Revista Latinoamericana de Filosofia Politica 2(1): 1-33.

Letsas, G. 2007. A Theory of Interpretation of the European Convention of Human Rights. Oxford: Oxford University Press.

Letsas, G. 2015. "Rescuing Proportionality." In Philosophical Foundations of Human Rights, edited by R. Cruft, M. Liao, and M. Renzo, 316-340. Oxford: Oxford University Press.

Luban, D. 2015. "Response to Buchanan." In Philosophical Foundations of Human Rights, edited by R. Cruft, M. Liao, and M. Renzo, 263-278. Oxford: Oxford University Press.

Miller, D. 2015. “Joseph Raz on Human Rights: A Critical Appraisal." In Philosophical Foundations of Human Rights, edited by R. Cruft, M. Liao, and M. Renzo, 232-243. Oxford: Oxford University Press.

Nickel, J. 2007. Making Sense of Human Rights, 2nd ed. Oxford: Blackwell.

Nickel, J. 2016. "Assigning Roles to Human Rights." In Human Rights: Moral or Political?, edited by A. Etinson, forthcoming. Oxford: Oxford University Press.

Nickel, J, and Reidy, D. 2010. "Philosophical Foundations of Human Rights." In International Human Rights Law, edited by D. Moeckli, S. Shah, and S. Sivakumaran, 39-63. Oxford: Oxford University Press.

Rawls, J. 1999. The Law of Peoples: with "The Idea of Public Reason Revisited". Cambridge, MA: Harvard University Press.

Raz, J. 2009. "Can there be a Theory of Law?" In J. Raz, Between Authority and Interpretation, 17-46. Oxford: Oxford University Press.

Raz, J. 2010a. "Human Rights without Foundations." In The Philosophy of International Law, edited by S. Besson, and J. Tasioulas, 321-337. Oxford: Oxford University Press.

Raz, J. 2010b. "Human Rights in the Emerging World Order." Transnational Legal Theory 1(1): 31-47.

Raz, J. 2013. "On Waldron's Critique of Raz on Human Rights." Oxford Legal Studies Research Paper No. 80/2013; Columbia Public Law Research Paper No. 13-359. Available at http:// ssrn.com/abstract=2307471. doi:10.2139/ssrn.2307471. Also In Human Rights: Moral or Political?, edited by A. Etinson, forthcoming. Oxford: Oxford University Press.

Raz, J. 2016. Normative Variations. Forthcoming.

Sen, A. 2009. The Idea of Justice. Cambridge, MA: Harvard University Press.

Tasioulas, J. 2007. "The Moral Reality of Human Rights." In Freedom from Poverty as a Human Right: Who Owes What to the very Poor?, edited by T. Pogge, 75--101. Oxford: Oxford University Press. 
Tasioulas, J. 2009. "Are Human Rights Essentially Triggers !

Compass 4(6): 938-950. doi:10.1111/j.1747-9991.2009.00_-ıu...

Tasioulas, J. 2010. "Taking Rights out of Human Rights." Ethics 120(4): 647-678. doi:10.1086/ 653432

Tasioulas, J. 2012. "Towards a Philosophy of Human Rights." Current Legal Problems 65(1): 1-30. doi:10.1093/clp/cus013

Tasioulas, J. 2016. "Philosophizing the Real World of Human Rights: A Reply to Samuel Moyn." In Human Rights: Moral or Political?, edited by A. Etinson, forthcoming. Oxford: Oxford University Press.

Valentini, L. 2012. "In What Sense Are Human Rights Political?: A Preliminary Exploration." Political Studies 60(1): 180-194. doi: 10.1111/j.1467-9248.2011.00905.x

Waldron, J. 2009. "Judges as Moral Reasoners." International Journal of Constitutional Law 7(1): 2-24. doi: $10.1093 /$ icon/mon035

Waldron, J. 2012. Dignity, Rank and Rights, edited by M. Dan-Cohen. Oxford: Oxford University Press.

Waldron, J. 2013. "Is Dignity the Foundation of Human Rights?" Paper presented at the NYU School of Law, Public Law Research Paper No. 12-73, January 2013.

Wellman, C. 2010. The Moral Dimension of Human Rights. New York; Oxford University Press.

\section{Further Reading}

Buchanan, A. 2015. "Why International Legal Human Rights?" In Philosophical Foundations of Human Rights, edited by R. Cruft, M. Liao, and M. Renzo, 244-262. Oxford: Oxford University Press.

Raz, J. 2010. "Human Rights without Foundations." In The Philosophy of International Law, edited by S. Besson, and J. Tasioulas, 339-355. Oxford: Oxford University Press. 